\title{
Assessment of perceived effects of climate change on rice production among farmers in North-west zone, Nigeria
}

\author{
D.H. YAKUBU*, J.G. AKPOKO, M.O. AKINOLA \& Z.ABDULSALAM \\ (D.H.Y.: Department of Agricultural Extension and Rural Development, Usmanu \\ Danfodiyo University, Sokoto; J.G.A. \& M.O.A.: Department of Agricultural \\ Extension and Rural Development, Ahmadu Bello University, Zaria; Z.A.: Department \\ of Agricultural Economics, Ahmadu Bello University, Zaria) \\ *Corresponding author'semail: danlami_y@yahoo.com/dhyakubu3@gmail.com
}

\begin{abstract}
Rice farming is highly dependent on environmental factors such as rainfall and temperature. Rice yield is affected by changes in these climatic elements. Rice farmers' perceptions of the changes in climate are important determinants of the management practices they use in reducing the effects on rice production. This study assessed the perceived effects of climate change on rice production among farmers. A multistage sampling procedure was used to obtain a sample of 522 farmers. Data were obtained with the aid of structured questionnaire. The data were analyzed using both descriptive and inferential statistics. Findings revealed that majority (94\%) of the respondents were males. They were married (88\%) and had farming as a major occupation $(89 \%)$. They perceived that climate change was posing risks to rice production $(\overline{\mathrm{X}}$ $=2.16)$, would lower rice production $(\bar{X}=2.07)$ and would continue to affect storage of rice $(\bar{X}$ $=2.01)$. The study determined a significant relationship $(\mathrm{p}<0.01)$ between farmers' perceived effects of climate change and rice yield. It was concluded that positive perception can lead to high adoption of climate change adaptation practices. The climate change knowledge-base of the farmers needs to be improved through more sensitization on climate smart agriculture.
\end{abstract}

Keywords: Climate change; awareness; perceived effects; rice production; farmers Original scientific paper. Received 23 July 2019; revised 13 Feb 2021

\section{Introduction}

There is growing evidence to suggest that climate change is real and has potentially devastating consequences on humanity (Intergovernmental Panel on Climate Change (IPCC) 2014). Evidence from literature and past studies has revealed that the recent global warming has influenced agricultural productivity leading to declining food production (Kurukulasuriya \& Mendelsohn, 2006; IISD, 2007; Lobell et al., 2008). Climate change has already affected crop yields in many countries (IPCC, 2007; Deressa et al., 2008; BNRCC, 2008). This is particularly true in low-income countries, where climate is the primary determinant of agricultural productivity and adaptive capacities are low (SPORE, 2008; Apata et al., 2009).

Climate change and agriculture have a unique relationship, which is well documented in literature (IPCC, 2014; Pidgeon \& Fischhoff, 2011; Pietsch \& McAllister, 2010).

Ghana Jnl Agric. Sci. 56 (1), $48-64$

GJAS is an Open Access Journal and distributed under the terms of the Creative Commons (CC) License [CC BY 4.0] 
This is particularly prevalent with regard to the influence on agricultural activities and subsequent crop yields. Agriculture depends much on the environment in the process of improving the lives and livelihoods of millions who depend on it for food and subsistence (Prantilla \& Laureto, 2013). Climate is the primary determinant of agricultural productivity. Climate change impact on agricultural inputs such as water for irrigation, amount of solar radiation for plant growth, and prevalence of pests can affect crop yield and types of crops that can be grown in some areas (Dhaka et al., 2010).

Rice farming is highly dependent on environmental factors which are the most important among several factors that influence agricultural production (Onyegbula, 2017). According to Edeh et al. (2011), rice production depends on optimum combination of factors of production in order to achieve remarkable yield. These factors are not limited to the familiar production inputs but include the various environmental factors provided by nature. Rainfall characteristics (intensity and duration), relative humidity and temperature constitute these weather-related and environmental factors that affect rice yield and its variability. The production of rice which is one of the world's most important crops in terms of food security and addressing poverty will be adversely affected as temperatures in rice-growing areas, increase with continued change in climate (Gumm, 2010).

Perception refers to beliefs or opinions often held by many people based on how things seem to them (Blaikie et al., 1997). Social scientists have found that public risk perceptions strongly influence the way people respond to hazards. Public perception is critical because it is a key component of the socio- political context within which policy makers operate. Public perception can fundamentally compel or constrain political, economic and social action to address particular risks (Falaki et al., 2013). Falaki et al. (2013) also identified perception as one factor that had almost been entirely omitted by a majority of researchers in climate change study. They asked how one could adapt to climate change in an adequate way if he did not perceive the current and future climate change as a reality. They asserted that it was reasonable to argue that the first step towards adaptation was the perception of the problem.

Farmer perceptions of climate change are important determinants of the type of management style adopted by the farmer (Thomas et al., 2007). Furthermore, individuals' appreciation of the veracity of climate change, degree of worry about climate change impacts and opinions on the personal and wider responsibilities for addressing the impacts of climate change are important in influencing climate action (Bord et al., 2000; Capsick et al., 2015; Kluckner, 2013; Tobler et al., 2012). The way in which individuals (including farmers) and societies respond to climate change has been closely linked to community perceptions of climate variability, as well as other consequences (IPCC, 2014; Pidgeon \& Fischhoff, 2011; Pietsch \& McAllister, 2010). As such, a lucid understanding of smallholder farmers' perceptions regarding climate variability and how it influences their farming practices is of critical importance.

Literature on climate change adaptation makes it clear that perception studies are necessary for the adoption of adaptation strategies (Maddison, 2006). Thus, a number of studies in Africa (Okonya 
et al., 2013; Simelton et al., 2013; Moyo et al., 2012; Penaranda et al., 2012; Gbetibouo, 2009; Maddison, 2006) have suggested that the success of any adaptation measures would depend on a farmers' positive perception about climate change and variability. The need to understand farmers' perception of climate change effects is necessary to determine the strategies they need to adopt in their attempt to minimize the adverse effects caused by the changes in climate. It is in this regard that this study is designed to assess the perceived effects of climate change on rice production among farmers in the North-west zone, Nigeria. It specifically describes the socioeconomic characteristics of the respondents, determines the climate change awareness level of the farmers, examines the perceived effects of climate change on rice production and determines the relationship between perceived effects of climate change and rice yield.

\section{The Study Area}

\section{Materials and Methods}

The study was conducted in three States namely: Kebbi, Sokoto and Zamfara of NorthWest zone, Nigeria. The zone, located between latitude $9^{0} 10^{1} \mathrm{~N}$ and $13^{0} 50^{1} \mathrm{~N}$ and longitude $3^{0} 35^{1} \mathrm{E}$ and $9^{0} 00^{1} \mathrm{E}$, covers about $168,719 \mathrm{~km}^{2}$. It consists of Jigawa, Kaduna, Kano, Kebbi,
Sokoto and Zamfara States. It leads the other zones in terms of population with a projected population of 46,694,805 million people (National Population Commission (NPC), 2015).

The zone's vegetation consists of Northern Guinea Savannah and Sudan Savannah, a vegetation belt covering most parts of the zone stretching from the Sokoto plains in the west, through the northern sections of the central highland. The low annual rainfall of usually less than $1000 \mathrm{~mm}$ and the prolonged dry season (6-9 months) sustain fewer trees and shorter grasses than the Southern Guinea Savannah. It is characterized by abundant short grasses of about 1.5-2 $\mathrm{m}$ and few stunted trees hardly above $15 \mathrm{~m}$. It is by far the most densely human-populated zone of northern Nigeria. Thus, the vegetation has undergone a severe destruction in the process of clearing land for the cultivation of important economic crops such as cotton, millet, maize and wheat. This is in addition to the devastation due to animal husbandry, especially cattle rearing, which is greatly favoured in this belt because the area is relatively free from tse-tse fly. The trees of the Sudan Savannah include the acacia, the shea-butter, baobab and the silk cotton (Online Nigeria, 2002; Yakubu et al., 2013). 


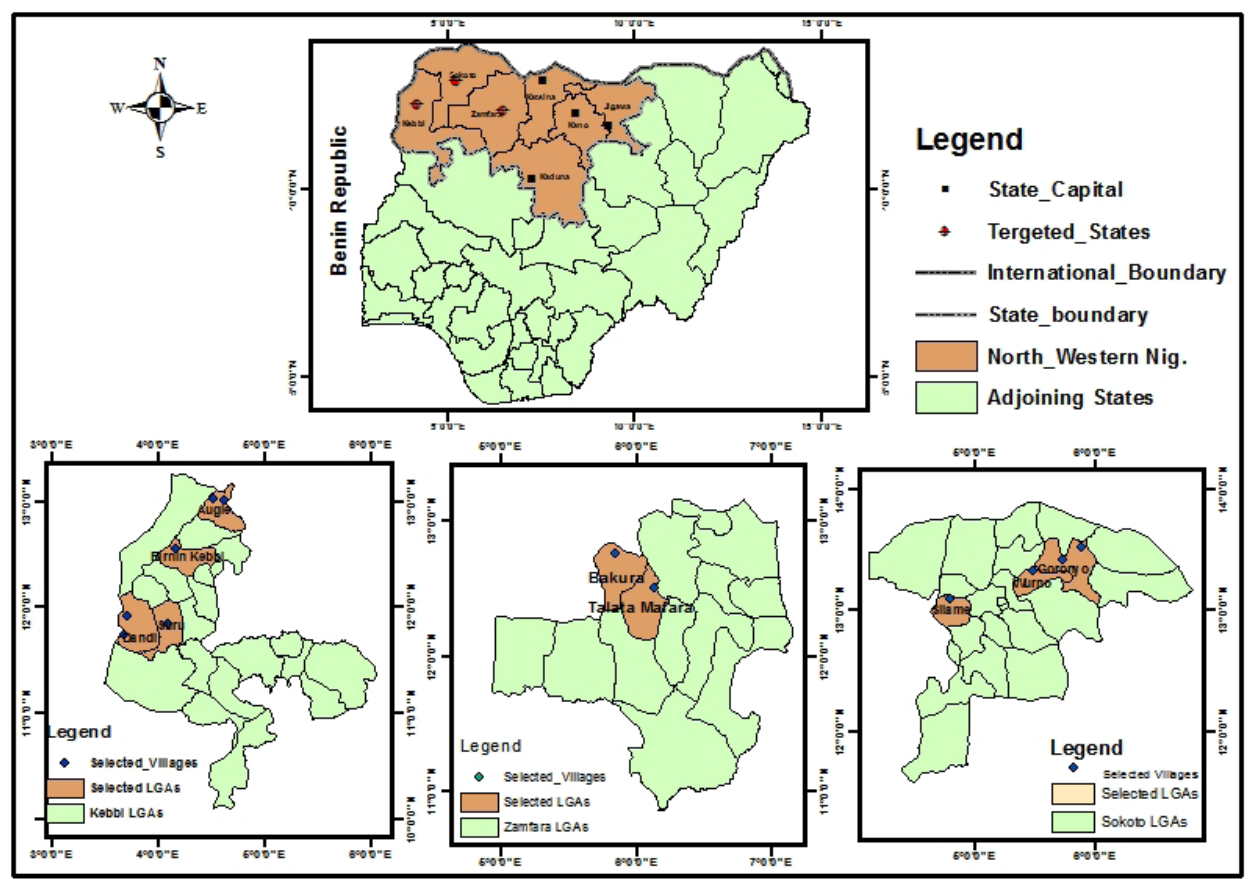

Fig. 1: Map of the Study Area

Sampling Procedure and Sample Size

This study targeted Sokoto, Kebbi and Zamfara States in the North-West, Nigeria. They are among the major rice-producing States in the country and the region in particular. A multistage sampling procedure was used to obtain the sample. In the first stage, four, out of the 20 major rice-producing LGAs, were purposively selected in Kebbi State based on the high population of rice farmers; three out of 14 LGAs in Sokoto and two out of 12 LGAs in Zamfara States. This gave nine out of 46 LGAs $(20 \%)$ in the three States. The LGAs chosen from Kebbi State included Augie, Dandi, Birnin Kebbi and Suru. Those from Sokoto State included Goronyo, Wurno and Silame. From Zamfara State, Bakura and Talata Mafara LGAs were selected.
The second stage was a purposive selection of 16 villages out of $286(5 \%)$, also based on high population of rice farmers, from the villages. In the third stage, 522 farmers (3\%) out of 17,071 (sampling frame) were randomly chosen from the selected villages to give the study sample.

\section{Method of Data Collection and analysis}

Primary data for this study, obtained with the aid of a structured questionnaire, were analyzed using both descriptive and inferential statistics. Descriptive statistics such as frequency counts, percentages, ranges and means were used to describe the socioeconomic characteristics of the farmers. Perception of the farmers on effects of climate change on rice production was captured using nine perceptional statements 
measured by a 3-point Likert type scale of $1=$ no effect, $2=$ low effect and $3=$ high effect. Linear regression analysis was used to determine the relationship between perceived effects of climate change and rice yield.

The linear regression model is specified as:

$\mathrm{Y}=\beta_{\mathrm{o}}+\beta_{1} \mathrm{X}_{1}+e$

Where;

$\mathrm{Y}=$ rice yield, $\mathrm{X}_{1}=$ perceived effects of climate change and rice yield, $\beta_{\mathrm{o}}=$ constant, $\beta_{1}=$ Coefficient to be estimated and $\mathrm{e}=$ error term. Rice yield was categorized into low $=$ 1 , medium $=2$ and high $=3$. Perception index was used to measure the perceived effects of climate change and rice yield.

\section{Results and Discussion}

Socioeconomic characteristics of the respondents

Socioeconomic characteristics discussed include age, sex, marital status, household size, educational qualification, farming experience and rice income of the respondents.

Age is an important factor not only for the knowledge of changes in the climate over time by the farmer but in making decision in the use of climate change adaptation practices. Majority of the respondents, about $60 \%$ in Kebbi and $75 \%$ in Sokoto States fell within the range of 41-60 years while 68\% in Zamfara State were found within the range of 21-40 years. Overall, about $62 \%$ fell within the 41-60 year range. The mean ages were about 46, 47 and 47 for Kebbi, Sokoto and Zamfara States, respectively with 47 being the overall average (Table 1). This result indicates that the respondents were still in their economically active age since the average age is less than 50 years.

TABLE 1

Distribution of respondents according to their socioeconomic characteristics

\begin{tabular}{|c|c|c|c|c|}
\hline & $\begin{array}{l}\text { Kebbi State } \\
(n=279)\end{array}$ & $\begin{array}{l}\text { Sokoto State } \\
(n=187)\end{array}$ & 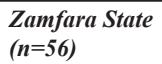 & Pooled Sample $(n=522)$ \\
\hline & $\%$ & $\%$ & $\%$ & $\%$ \\
\hline \multicolumn{5}{|c|}{ Age (years) } \\
\hline $21-40$ & 36.92 & 23.00 & 67.86 & 35.25 \\
\hline $41-60$ & 59.88 & 74.86 & 25.00 & 61.49 \\
\hline Above 60 & 3.20 & 2.14 & 7.14 & 3.26 \\
\hline Mean age & 45.77 & 46.48 & 47.34 & 46.53 \\
\hline \multicolumn{5}{|l|}{ Sex } \\
\hline Male & 93.19 & 94.12 & 92.86 & 93.49 \\
\hline Female & 6.81 & 5.88 & 7.14 & 6.51 \\
\hline \multicolumn{5}{|c|}{ Marital status } \\
\hline Married & 84.95 & 92.51 & 85.71 & 87.74 \\
\hline Single & 5.38 & 1.60 & 5.36 & 4.02 \\
\hline Widow & 6.45 & 5.35 & 3.36 & 5.94 \\
\hline Widower & 3.23 & 0.53 & 3.52 & 2.30 \\
\hline \multicolumn{5}{|c|}{ Household size } \\
\hline Below 5 & 16.13 & 12.30 & 12.50 & 14.37 \\
\hline $5-9$ & 27.60 & 36.36 & 8.93 & 28.74 \\
\hline
\end{tabular}




\begin{tabular}{lllll}
$10-14$ & 44.80 & 45.46 & 14.29 & 41.76 \\
$15-19$ & 11.47 & 3.74 & 39.29 & 11.67 \\
Above 19 & 0.00 & 2.14 & 25.00 & 3.45 \\
Mean household size & & & & \\
& $\mathbf{1 1 . 1 4}$ & $\mathbf{1 4 . 1 1}$ & $\mathbf{1 8 . 8 6}$ & $\mathbf{1 4 . 7 0}$ \\
Highest educational qualification & & & \\
Non formal & 39.01 & 54.01 & 41.07 & 44.64 \\
Primary & 11.11 & 22.46 & 23.21 & 16.48 \\
Secondary & 33.33 & 18.72 & 28.57 & 27.59 \\
Tertiary & 16.49 & 4.81 & 7.14 & 11.30 \\
Farming experience (years) & & & & \\
5-9 & 5.38 & 4.81 & 3.52 & 4.98 \\
$10-14$ & 9.32 & 10.16 & 8.93 & 9.58 \\
15-19 & 6.09 & 13.37 & 12.50 & 9.39 \\
20-24 & 32.26 & 52.41 & 21.43 & 38.31 \\
$25-29$ & 29.75 & 11.23 & 33.93 & 23.56 \\
Above 29 & 17.20 & 8.02 & 19.64 & 14.18 \\
Mean farming experience & & & & \\
Income from rice production (N) & $\mathbf{2 4 . 6 4}$ & $\mathbf{2 4 . 9 8}$ & $\mathbf{2 6 . 8 6}$ & $\mathbf{2 5 . 4 9}$ \\
Below 50000 & 2.15 & & & \\
50000-499999 & 80.65 & 0.00 & 1.79 & 1.34 \\
500000-949999 & 10.75 & 95.72 & 83.93 & 86.40 \\
More than 949999 & 6.45 & 4.28 & 14.29 & 8.81 \\
Mean rice income & $\mathbf{3 7 0 , 9 3 3 . 2 0}$ & $\mathbf{2 3 9 , 5 1 6 . 0 0}$ & $\mathbf{3 1 5 , 7 7 6 . 8 0}$ & $\mathbf{3 0 8 , 7 4 2 . 0 0}$ \\
\hline
\end{tabular}

This finding agrees with Adebayo et al. (2012) who reported, in a study to determine farmers' awareness, vulnerability and adaptation to climate change in Adamawa State, Nigeria, that about $51 \%$ of the farmers were between $31-50$ years and about $26 \%$ of the farmers were up to 30 years of age, while farmers that were over 50 years of age constituted about $23 \%$. This implies that most of the farmers were relatively young and physically active. They stressed that the finding had a direct bearing on the availability of able-bodied manpower for agricultural production and also on the ease of use of climate change adaptation strategies. Also, age influenced the ability to seek and obtain off-farm jobs and income, which could increase farmers' income and could help cope with adverse change in climate.
Majority of the respondents, about $93 \%$ in Kebbi, 94\% in Sokoto and 93\% in Zamfara States were males. Overall, about $94 \%$ of them were males (Table 1). This indicates that rice farming in these three States is dominated by males. It agrees with Ishaya and Abaje (2008) and Abraham et al. (2012) who reported that the agricultural sector and the tedious activities related to climate change adaptation strategies are dominated by males.

Majority of the respondents, about $85 \%$ in Kebbi, $93 \%$ in Sokoto and $86 \%$ in Zamfara States were married. Overall, 88\% of them were married (Table 1). Marriage is an important aspect of the life of the farmers. Every individual who attained the right age is expected to marry, hence, only about $5 \%, 2 \%$ 
and $5 \%$ of the respondents were found single in Kebbi, Sokoto and Zamfara States, respectively. It indicates that majority of the respondents were saddled with the responsibility of catering for their families. This can create the need for portfolio diversification as a climate change adaptation strategy, in order to meet the various needs of the family members.

Table 1 shows that about $45 \%$ and $46 \%$ of the respondents in Kebbi and Sokoto States, respectively, had a family size of 10-14 individuals. A larger proportion of the farmers in Zamfara State (39\%) had 15-19 members in their households. Overall, about $42 \%$ of the respondents had a family size of 10-14 individuals. The mean household sizes were about 11, 14 and 19 for Kebbi, Sokoto and Zamfara States, respectively with an overall mean of about 15 (Table 1). This indicates that majority of the respondents had at least 10 individual members in their households. This is on the high side due to the polygamous lifestyle of the farmers and for the fact that unmarried sons often remain in the family. Large household size can put immense pressure on household food demand which influences households to employ climatesmart practices to ensure sustainable food production.

Household size is the function of spouses, children and dependants staying and eating under the same household head (Fatuase et al., 2015). Ordinarily, this will make the farming households accomplish various agricultural tasks as a result of higher labour endowments as reported by Deressa et al. (2010). Abaje et al. (2014) observed that large household size is believed to provide cheap labour that will assist in practices that will mitigate the impacts of climate variability and change by the respondents. This is because some of the resources and items that could be used in combating the impacts of climate variability and change cannot be afforded as the average annual income of the farmers is too meagre.

Results of the study reveal that over $55 \%$ of the total respondents, $60 \%$ in Kebbi State had primary, secondary or tertiary education. Similarly, about $59 \%$ of the respondents in Zamfara State had primary, secondary or tertiary education. However, a larger segment (54\%) of the respondents in Sokoto States had no formal education (Table 1). This implies that majority of the respondents in Kebbi and Zamfara States had one form of formal education or another, while their counterparts in Sokoto State had mainly Qur'anic education which is non-formal education. The argument of formal education can be expanded to include the fact that education can pull household members into off-farm activities such as civil service and trading that are more remunerative relative to on-farm activities such as crop and livestock production. This will have a negative repercussion on adopting climate-smart adaptation practices with subsequent negative effects on agricultural production.

Formal education among farmers can favour their use of climate change adaptation practices through their literacy level (Anyoha et al., 2013). This agrees with Adebayo et al. (2012) who reported that about $70 \%$ of the farmers in Adamawa State, Nigeria had some form of formal education and concluded that the literacy level among the farmers was high and which could have implication for agricultural production and also for the adaptation to changes in the climate. They observed the adoption of measures that could result in climate change adaptation is also easier and faster among the educated farmers than the uneducated farmers. 
About $32 \%$ and $52 \%$ of the respondents in Kebbi and Sokoto States, respectively, had a farming experience of 20-24 years, while $33.93 \%$ of the respondents in Zamfara State had an experience of 25-29 years. Overall, $38.31 \%$ of the respondents had $20-24$ years of farming experience (Table 1). The fact that none of the respondents had an experience of less than five years indicates that they were not new to farming. The mean farming experience was 25.49 , specifically, 24.64, 24.98 and 26.86 years for Kebbi, Sokoto and Zamfara State farmers, respectively.

The more experienced the farmer is, the more he/she is better informed about the changes in climate and the more he/she is likely to employ adaptation measures that reduce the impact of climate change on his/her agricultural activities (Mudzonga, 2012). It is the farming experience that matters more than merely the age of the farmer when it comes to adaptation to climate change (Hassan \& Nhemachena, 2008). Studies by Maddison (2006) and Hassan and Nhemachena (2007) indicated that more farming experience increases the probability of a farmer adapting to climate change.
Rice income refers to the earnings, returns or proceeds of cash or cash-equivalents received by the farmers from rice production. Results of the study show that majority of the respondents, about $81 \%$ in Kebbi, $96 \%$ in Sokoto and $84 \%$ in Zamfara States had an income from rice production, within the range of $\mathrm{N} 50,000.00$ to $\mathrm{N} 499,999.00$. Overall, about $86 \%$ of them had their income from rice production, within the $\$ 50,000.00$ to $\$ 499,999.00$ range. The mean rice income

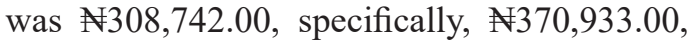
$\$ 239,516.00$ and $\$ 315,776.80$ for Kebbi, Sokoto and Zamfara State farmers, respectively (Table 1).

Climate change awareness level of the farmers Climate change awareness was determined through the farmers' awareness of changes in rainfall and temperature patterns over time. The result of this study shows that about $51 \%$ of the respondents in Kebbi State, 26\% in Sokoto State and $36 \%$ in Zamfara State were fully aware of climate change. Overall, about $40 \%$ of the respondents were fully aware of climate change. Only $25 \%$ of the respondents, $18 \%$ in Kebbi State, 33\% in Sokoto State and 34\% in Zamfara State were not aware of climate change (Table 2).

TABLE 2

Distribution of respondents according to climate change awareness

\begin{tabular}{|c|c|c|c|c|}
\hline & $\begin{array}{r}\text { Kebbi State } \\
\quad(n=279)\end{array}$ & $\begin{array}{l}\text { Sokoto State } \\
(n=187)\end{array}$ & $\begin{array}{l}\text { Zamfara } \\
\text { State }(n=56)\end{array}$ & $\begin{array}{l}\text { Pooled Sample } \\
(n=522)\end{array}$ \\
\hline & $\%$ & $\%$ & $\%$ & $\%$ \\
\hline \multicolumn{5}{|c|}{ Climate change awareness level } \\
\hline Not aware & 17.93 & 33.16 & 33.93 & 25.10 \\
\hline Partially aware & 31.18 & 40.64 & 30.36 & 34.48 \\
\hline Fully aware & 50.90 & 26.20 & 35.71 & 40.42 \\
\hline
\end{tabular}


Perceived causes of climate change

Destruction of vegetation

Super natural forces/God

Do not know

Poor farming practices

Climate change awareness period

2-6

7-11

12-16

$17-21$

Mean climate change awareness period

Climate change sensitization

Attended seminar/workshop or meeting on climate change

13.26

Attended no seminar/workshop or meeting on climate change

86.74

50.66

37.12

10.04

6.11

68.80

65.78

79.55

70.31

52.94

58.93

59.00

3.21

2.27

43.32

48.21

46.94

Information obtained at the sensitization

Causes of climate change

100.00

Effects of climate change on agriculture

Climate change adaptation practices

Sources of climate change awareness

Radio

Television

Newspapers

Extension agent

Internet

Fellow farmers

Research institutes

Cooperative societies
59.83

23.58

3.06

2.62

100.00

100.00

93.01

0

0
36.00

0.00

1.60

0.00

0.00

7.09

100.00

100.00

92.91

2.70

59.08

78.38

27.03

41

0.00

7.09

0.00

0.00

7.09

0.00

0.00

7.09

99.20

97.30

97.19

31.20

37.84

48.59

7.20

13.51

17.31

0.00

16.22

3.32

0.00

0.00

1.54

88.80

97.30

92.33

0

0

0

0

0

0

*Multiple responses 
This implies that majority of the respondents were aware (either fully or partially) of climate change. Climate change awareness is the first step in learning and using climate change adaptation practices. Awareness of climate change helps farmers plan their production activities and reduces risks and uncertainties associated with farming (Adebayo et al., 2012).

Farauta et al. (2011) found that farmers in Northern Nigeria were aware and knowledgeable on the issues of climate change. They added that awareness is a necessary step in adapting to the changing climate. Gworgwor (2008) stated that the uncertainty on the magnitude of change makes awareness imminent at all levels. Gworgwor (2008) also suggested that the present solution to man's survival on the earth's environment sustainably hinges on the option of knowledge of climate variability and adopting mitigation and adaptation measures as widely recognized as vital components or approaches to reducing climate variability. Awareness of climate change helps farmers plan their production activities and reduces risks and uncertainties associated with farming (Adebayo et al., 2012).

Access to information on climate change influences the farmers' awareness of changes in climate and creates opportunities for the farmer to adopt suitable strategies that best suit the changed climatic conditions (Mudzonga, 2012). Extension services are made available to the farmer by the government. They serve as technical information sources to farmers. Such services provide the farmer with information about the agricultural adaptation practices that are most suitable to their farms. Extension services also inform the farmers about the changing climatic conditions (Mudzonga, 2012). Provision of such services enhances the chances of the farmers to adapt to climate change. Thus, exposure to such information increases the farmer's awareness. Hassan and Nhemachena (2007) found that access to information about climate change forecasting, adaptation options and other agriculture activities remain important factors determining the use of various adaptation strategies.

Change in climate occurs gradually over a long period. Awareness of climate change among farmers does not start at the same period. This study, therefore, reveals that majority of the respondents, about 51\% in Kebbi, 59\% in Sokoto and 78\% in Zamfara States were aware of climate change for a period of 2-6 years. Overall, about $60 \%$ of them were aware of climate change for a period of 2-6 years. Few of the farmers (4\%) were aware of climate change in over a 16 -year period. The mean awareness period was 5 for the entire respondents, 7, 4 and 4 years for Kebbi, Sokoto and Zamfara State farmers, respectively (Table 2 ). This indicates that the farmers were aware of climate change at different periods within a range of 2-21 years.

Sensitization on climate change can enhance its understanding by farmers and increase the chances of using climate change adaptation strategies. Only about $13 \%$ of the respondents who were found mainly in Kebbi State attended seminars/workshops or meetings on climate change (Table 2). This implies that climate change sensitization was too low in the study area.

The entire respondents (100\%) found in Kebbi State, who attended seminars/workshops or meetings on climate change, revealed that they obtained information on causes of climate change and its effects on agriculture (Table 2). This indicates that the information obtained by 
the farmers was relevant to their agricultural production activities.

Sources of climate change awareness refer to the channels through which information on climate change gets to the farmers. This study shows that majority of the respondents, about $96 \%$ in Kebbi, 99\% in Sokoto and 97\% in Zamfara States had radio as their source of climate change awareness. Overall, $97 \%$ of the farmers had radio as their source of climate change awareness. Similarly, majority of them, $93 \%$ in Kebbi, $89 \%$ in Sokoto and $97 \%$ in Zamfara States relied on fellow farmers as their source of climate change awareness. Overall, $92 \%$ of the respondents relied on fellow farmers as their source of climate change awareness (Table 2).

This implies that radio and fellow farmers were the most important sources of climate change awareness among the farmers. This finding agrees with Farauta et al. (2011) who reported that the mass media especially radio and televisions were the major avenues through which farmers sourced information on climate change. Isife and Ofuoku (2008) documented that radio has the highest audience and had the strength of reaching a large population of farmers and other rural dwellers faster than other means of communication. The implication of this finding is that there is a need for extension services to rise to the challenge of dissemination of information on climate change issues using the radio and television (mass media).

\section{Perceived effects of climate change on rice production}

Results of this study revealed that among the farmers' perceived effects of climate change on rice production, climate change posing risks to rice production had the highest mean of 2.16 among the respondents. Specifically, it had a mean of 2.26 in Kebbi State, 2.18 in Sokoto State and 2.05 in Zamfara State. This was followed by the perception that climate change would lower rice production having an overall mean score of 2.07, with specific scores of 2.22, 2.15 and 1.84 in Kebbi State, Sokoto State and Zamfara State, respectively. The belief among the respondents that climate change would continue to affect storage of rice had an overall mean score of 2.01. It specifically had the mean scores of 2.20, 2.08 and 1.76 in Kebbi State, Sokoto State and Zamfara State, respectively (Table 3). 
TABLE 3

Distribution of respondents according to perceived effects of climate change on rice production

\begin{tabular}{|c|c|c|c|c|c|}
\hline & Perceived effects of Climate Change & $\begin{array}{l}\text { Kebbi State } \\
(n=279) \\
\text { Mean }\end{array}$ & $\begin{array}{l}\text { Sokoto } \\
\text { State } \\
(n=187) \\
\text { Mean }\end{array}$ & $\begin{array}{l}\text { Zamfara } \\
\text { State } \\
(n=56) \\
\text { Mean }\end{array}$ & $\begin{array}{l}\text { Pooled Sample } \\
(n=522) \\
\text { Mean }\end{array}$ \\
\hline$i$. & $\begin{array}{l}\text { Climate change poses risks to rice } \\
\text { production }\end{array}$ & 2.26 & 2.18 & 2.05 & 2.16 \\
\hline ii. & $\begin{array}{l}\text { Climate change presents more risks } \\
\text { than benefits to rice production }\end{array}$ & 2.14 & 1.79 & 1.67 & 1.87 \\
\hline iii. & $\begin{array}{l}\text { Continuous rise in annual temperature } \\
\text { reduces production of rice }\end{array}$ & 1.88 & 1.85 & 1.63 & 1.79 \\
\hline iv. & $\begin{array}{l}\text { Yearly rains are not supporting rice } \\
\text { production as before }\end{array}$ & 2.08 & 1.57 & 1.51 & 1.72 \\
\hline v. & $\begin{array}{l}\text { Infestation of rice by pest is common } \\
\text { due to climate change }\end{array}$ & 1.91 & 1.81 & 1.60 & 1.77 \\
\hline vi. & $\begin{array}{l}\text { Climate change reduces working hours } \\
\text { of rice farmers }\end{array}$ & 1.89 & 1.41 & 1.56 & 1.62 \\
\hline vii. & $\begin{array}{l}\text { There is poor germination rate of rice } \\
\text { due to climate change }\end{array}$ & 1.96 & 1.72 & 1.78 & 1.82 \\
\hline viii. & $\begin{array}{l}\text { Climate change will lower rice pro- } \\
\text { duction }\end{array}$ & 2.22 & 2.15 & 1.84 & 2.07 \\
\hline ix. & $\begin{array}{l}\text { Climate change will continue to affect } \\
\text { storage of rice }\end{array}$ & 2.20 & 2.08 & 1.76 & 2.01 \\
\hline
\end{tabular}

Climate change presenting more risks than benefits to rice production scored an overall mean of 1.87. It had mean scores of 2.14, 1.79 and 1.67 in Kebbi State, Sokoto State and Zamfara State, respectively. Continuous rise in annual temperature reducing production of rice scored an overall mean of 1.79 , with specific mean scores of 1.88, 1.85 and 1.63 in Kebbi State, Sokoto State and Zamfara State, respectively. Next in the ranks was infestation of rice by pests being common due to climate change, with an overall mean of 1.77 and specific mean scores of 1.91, 1.81 and 1.60 in Kebbi State, Sokoto State and Zamfara State, respectively (Table 3 ).

With the mean score of at least 1.5 out of the possible 3.00 , it indicates that majority of the respondents had a positive perception of climate change effects on rice production. In other words, they believed that climate change can impact negatively on rice production. Such perception or belief can motivate the farmers to take action within their context, thereby favouring the use of climate change adaptation practices. Adebayo et al. (2012) reported that majority of farmers in Adamawa State claimed that climate change has affected farming activities in recent years.

According to Haddad (2005) one factor that has almost been entirely omitted by majority of researchers is perception. How can one adapt to climate change adequately if he does not perceive the current and future climate change as a reality? It is reasonable to argue that the first step towards adaptation is the perception of the problem. However, research on the adaptation of small-scale farmers in Nigeria has often occurred in the absence of 
knowledge of rural farmers' perception about climate change, its causes and impact, as well as existing adaptation responses (Falaki et al., 2013).

Relationship between perceived effects of climate change and rice yield

Table 4 presents linear regression estimates for the relationship between farmers' perceived effects of climate change on rice production and rice yield. There is a positive and significant $(\mathrm{p}<0.00)$ relationship between farmers' perceived effects of climate change and rice yield. With reference to the overall fit of the regression model, the obtained $\mathrm{R}^{2}$ adjusted $(0.823)$ suggests that the predictor variable was significant in explaining the dependent variable. This implies that the farmers' perception of climate change had strong and positive effects on rice yield. The realization of such effects could lead to the application of climate change adaptation practices by the farmers, which would lead to higher rice yields.

TABLE 4

Relationship between perceived effects of climate change and rice yield

\begin{tabular}{lcccc}
\hline Variable & $\begin{array}{l}\text { Coef- } \\
\text { ficient }\end{array}$ & $\begin{array}{l}\text { Stan- } \\
\text { dard } \\
\text { error }\end{array}$ & t-ratio & $\boldsymbol{P}|\boldsymbol{T}|>\boldsymbol{t}]$ \\
\hline $\begin{array}{l}\text { Constant } \\
\text { Perceived } \\
\text { effects of }\end{array}$ & -0.716 & 0.053 & -13.504 & 0.000 \\
$\begin{array}{l}\text { climate } \\
\text { change on } \\
\text { rice yield }\end{array}$ & 0.039 & 0.001 & 49.146 & $0.000^{* * *}$ \\
Adjusted R-squared $=0.823$ & & \\
\hline
\end{tabular}

***Significant at $1 \%$ level

\section{Conclusions and Recommendations}

Among the farmers' perceived effects of climate change on rice production were climate change posing risks and lowering rice production in the study area. These perceptions on the fact that climate change has adverse effect on rice production from germination to storage exhibited by the farmers are positive and good. Hence, can ginger the farmers towards using the adaptation strategies that can minimize the adverse effects. Positive perceptions can lead to increased application of climate change adaptation practices, which will, in turn, lead to higher rice yields.

Reliance of the farmers on the radio and fellow farmers as the main sources of information on climate change may restrict their full knowledge of the causes, impacts and climate change adaptation strategies. Besides, more positive perceptions are needed by the farmers for adopting more climate smart production practices for increase in rice yield in the study area.

Climate change awareness creation among farmers should not depend mainly on radio and fellow farmers. Seminars/workshops on climate change and related issues should also be organized by both government and Non-Governmental Organizations (NGOs), as stakeholders in encouraging the practice of climate smart agriculture.

The good perceptions on the effect of climate change on rice production exhibited by the farmers should be used by all stakeholders in climate smart agriculture (both governmental and non-governmental organizations) to help them in improving rice production. This can be done through organizing seminars and workshops for the farmers. Valuable information especially on causes of climate change and its impact on agriculture can easily be provided to the farmers. The farmers can also be sensitized on more strategies for climate change adaptation for improved yields. More sources of climate information should be available to the farmers for improved productivity. 


\section{Acknowledgement}

We are thankful to the authorities of Usmanu Danfodiyo University, Sokoto for sponsoring this study. We appreciate the assistance rendered by Rice Farmers Association of Nigeria (RIFAN) and Agricultural Development Programmes of Sokoto, Kebbi and Zamfara States, Nigeria.

\section{REFERENCES}

Abaje, I.B.; Sawa, B.A. \& Ati, O.F. (2014) Climate Variability and Change, Impacts and Adaptation Strategies in Dutsin-Man Local Government Area of Katsina State,Nigeria; Journal of Geography and Geology 6 (2), 68 - 72.

Abraham, F., Bamidele, F. S., Adebola, A. J., \& Kobe, I. H. (2012) Climate change mitigating activities and determinants in the rural guinea savannah of Nigeria. Journal of Sustainable Agriculture Research 1 (2), 170 177.

Adebayo, A.A., Onu, J.I., Adebayo, E.F. \& Anyanwu, S.O. (2012) Farmers' Awareness, Vulnerability and Adaptation to Climate Change in Adamawa State, Nigeria; British Journal of Arts and Social Sciences 9 (2), $104-115$.

Adger, N.W., Dessai, S., Goulden, M., Hulme, M., Lorenzoni, I., Nelson, D. R., Naess, O. L., Wolf, J. \& Wreford, A. (2008) Are there social limits to adaptation to climate change? Springer Science + Business Media B.V. Climatic Change 93, 335 - 354.

Anyoha, N. O., Nnadi, F. N., Chikaire, J., Echetama, J. A., Utazi, C. O. \& R. A. Ihenacho. (2013) Socio-economic factors influencing climate change adaptation among crop farmers in Umuahia South Area of Abia State, Nigeria, Net Journal of Agricultural Science 1 (2), 42 -47 .

Apata, T.G., Samuel, K.D. \& Adeola, A.O. (2009) Analysis of Climate Change Perception and Adaptation among Arable Food Crop Farm- ers in South Western Nigeria, Contributed Paper Prepared for Presentation at the International Association of Agricultural Economists' 2009 Conference, Beijing, China, August $16^{\text {th }}-22^{\text {nd }}$.

Blaikie, P., Brown, K., Stocking, M., Tang, L., Dixon, P. \& Sillitoe, P. (1997) Knowledge in Action: Local Knowledge as a Development Resource and Barriers to its Incorporation in Natural Resource Research and Development. Great Britain: Elsevier Science Ltd. Agricultural Systems 55 (2), 217 - 237.

Bord, R.J., Robert, E.O. \& Fisher, A. (2000) In what sense does the public need to understand Global Climate Change? Public Understanding of Science 9, $18-25$.

Building Nigeria's Response to Climate Change. (BNRCC). (2008) Annual Workshop of

Nigerian Environmental Study Team (NEST): The Recent Global and Local Action on Climate Change, held at Hotel Millennium, Abuja, Nigeria; $8^{\text {th }}-9^{\text {th }}$ October.

Capsick, S. Whitmarsh, L. Poortinga, W., Pidgeon, N. \& Upham, P. (2015) International Trends in Public Perceptions of Climate Change over the Past Quarter Century, Climate Change 6, 35-6.

Corina, H. \& Larraine, E. W. (2011) Public Engagement in Climate Action: Policy and Public Expectaions. In: Engaging the Public with Climate Change, Behaviour Change and Communication. Lorraine, E. Whitmarsh, Saffron, O'Neill and Irene, Lorenzoni. London: Earthscan, $47-55$.

Deressa, T.T., Hassen, R., Alemu, T., Yesuf, M. \& Ringler, C. (2008) Analyzing the determinants of farmers' choice of adaptation measures and perceptions of climate change in the Nile Basin of Ethiopia. International Food Policy Research Institute (IFPRI) Discussion Paper No. 00798. Washington, DC: IFPRI. 
Deressa, T. T., Ringler, C. \& Hassan, R.M. (2010) Factors affecting the choices of coping strategies for climate extremes: the case of farmers in the Nile Basin of Ethiopia (Final START, ACCFP Report) African Climate Change Fellowship Program (ACCFP).

Dhaka, B., L. Chayal, K. \& Poonia, M.K. (2010) Analysis of Farmers' Perception and Adaptation Strategies to Climate Change. Libyan Agriculture Research Center Journal International 1(6), 388 - 390 .

Edeh, H.O., Eboh, E.C. \& Mbam, P.N. (2011) Analysis of Environmental Risk Factors Affecting Rice Farming in Ebonyi State, Southeastern Nigeria, World Journal of Agricultural Science 7 (1), $100-103$.

Falaki, A.A., Akangbe, J.A. \& Ayinde, O.E. (2013) Analysis of Climate Change and Rural Farmers' Perception in North Central Nigeria. Journal of Human Ecology, 43 (2), 133 -140 .

Farauta, B.K., Egbule, C.L., Idrisa, Y.L. \& Agu, V.C. (2011) Climate Change and Adaptation Measures in Northern Nigeria: Empirical Situation and Policy Implications, Working Paaper Series Number 62, The African Technology Policy Studies Network (ATPS), p. 34.

Fatuase, A.I., Aborisade A.S. \& Omisope, E.T. (2015) Determinants of Adaptation Measures to Climate Change by Arable Crop Farmers in Owo Local Government Area of Ondo State, Nigeria, World Rural Observations 7 (1).

Available at http://www.sciencepub.net/rural

Fatuase, A.I. \& Ajibefun, I. (2014) Perception and Adaptation to Climate Change among Arable Crop Farmers in Selected Communities of Ekiti State, Nigeria. Journal of Agricultural Faculty of Gaziosmanpasa University 31 (3), $101-114$.
Gbetibouo, G. A. (2009) Understanding Farmers' Perceptions and Adaptations to Climate Change and Variability: The Case of the Limpopo Basin, South Africa. In: International Food Policy Research Institute, 52. Greene, W. H. (2002) Econometric analysis, Fifth edit., 827. New York University.

Greene, W. H. (2012) Econometric analysis, Seventh ed., 1231. New York University.

Gumm, D. (2010) Nigeria: Climate Change to Affect Rice Yields. Vanguard, August19. Retrieved September 20, 2011 from http://allafrica.com/ nigeria/climate.

Gworgwor, N.A. (2008) Climate Change and Sustainable Rural Livelihood in the Sudan- Sahelian Zone of Nigeria. In: Akande $\mathrm{T}$ and Kumuji A (Eds.), Challenges of Climate Change for Nigeria.

Haddad, B.M. (2005) Ranking the Adaptive Capacity of Nations to Climate Change when Socio-political Goals are Explicit. Global Environmental Change 15, 165 - 176.

Hassan, R., \& Nhemachena, C. (2007) Micro-Level Analysis of Farmers' Adaptation to Climate Change in Southern Africa, IFPRI Discussion Paper 00714, August 2007.

Hassan, R. \& Nhemachena, C. (2008) Determinants of African Farmers' Strategies for Adapting to Climate Change: Multinomial Choice Analysis, African Journal of Agricultural and Resource Economics 2 (1), 83 - 104.

Intergovernmental Panel on Climate Change (IPCC) (2007) Climate Change In: Parry, Martin L., Canziani, Osvaldo F., Palutikof, Jean P., van der Linden, Paul J., and Hanson, Clair E. (eds.) Impacts, Adaptation, and Vulnerability. Contribution of Working Group II to the Third Assessment Report of the Intergovernmental Panel on Climate Change Cambridge University Press, Cambridge, United Kingdom, p. 1000. 
Intergovernmental Panel on Climate Change (IPCC) (2014) Impacts, Adaptation and Vulnerability. Contribution of Working Group II to the Fifth Assessment REPORT on the Intergovernmental Panel on Climate Change; Cambridge university press, Cambridge.

International Institute for Sustainable Development [IISD] (2007) Community-based adaptation to climate change Bulletin. A summary of the second International Workshop on Community-based adaptation to climate change. IISD reporting services.

Ishaya, S. \& Abaje, I.B. (2008) Indigenous people's perception on climate change and adaptation strategies in Jema'a local government area of Kaduna State, Nigeria. Journal of Geography and Regional Planning 1 (8), 138 - 143, November, 2008. Academic Journals. http:// acadjourn.org/JGRP/PDF/Pdf2008/Nov/Ishaya\%20and $\% 20$ Abaje.pdf.

Kluckner, C.A. (2013) A Comprehensive Model of the Psychology of Environmental Behaviour - A Meta Analysis, Global Environmental Change 23, $28-38$.

Kurukulaluriya P \& Mendelson. R. (2006) A Ricardian Analysis of the Impact of Climate Change on Africa Cropland. C EEPA discussion paper No. 8. Centre for Environmental Economic and Policy in Africa, University of Pretoria.

Leiserowitz, A.A. (2005) American Risk Perceptions: Is Climate Change Dangerous? Risk Analysis 25 (6), 1433 - 1442.

Lobell, D.B., Burke, M.B., Tebaldi, C., Mastrandrea, M.D., Falcon, W.P. \& Naylor, R.L. (2008) Prioritizing Climate Change Adaptation Needs for Food Security in 2030.

Science 319 (5863), $607-610$.

Maddison, D. (2006) The Perception of and Adaptation to Climate Change in Africa; (CEEPA
Discussion Paper No. 10). Centre for Environmental Economics and Policy in Africa, University of Pretoria, South Africa.

Moyo, M., Mvumi, B. M., Kunzekweguta, M., Mazvimavi, K. \& Craufurd, P. (2012) Farmer perceptions on climate change and variability in semi-arid Zimbabwe in relation to climatology evidence. African Crop Science Journal $20,317-335$.

Mudzonga, E. (2012) Farmers' Adaptation to Climate Change in Chivi District of Zimbabwe. Accessed 18/8/2015. Available at www.trapca. org/.../Evengelista_adaptationtoclimatechangerevised.pdf.

National Population Commission (NPC) (2015) Federal Republic of Nigeria, 2006 Population Census. National Population Commission, www.nigerianstat.gov.ng.

Okonya, J. S., Syndikus, K. \& Kroschel, J. (2013) Farmers' Perception of and Coping Strategies to Climate Change: Evidence from Six Agro-Ecological Zones of Uganda 5 (8), 252 - 263. doi:10.5539/jas.v5n8p252

OnlineNigeria (2002) Vegetation. Daily news. www. onlinenigeria.com. Retrieved on $24^{\text {th }}$ May, 2010 .

Onyegbula, C.B. (2017) Rice Farmers Perception of Effects of Climate Change on Rice Development Stages in Niger State, Journal of Agricultural Extension and Rural Development, available at http://www.academicjournals.org/ JAERD, Accessed on $29 / 12 / 2017$

Penaranda, I., Perrino, E. S. \& Barreras, E. (2012) Farmers' Perceptions of Climate Change: A Case Study in the Abura-Aseibu-Kwamankese district, Central Region, Ghana.

Pietsch, J. \& McAllister, I. (2010) A Diabolical Challenge: Public Opinion and Climate Change Policy in Australia, Environmental Politics 19, $21-36$. 
Pidgeon, N. \& Fischhoff, B. (2011) The Role of Social and Decision Sciences in Communicating Uncertain Climate Risks, Nature Climate Change 1, $35-41$.

Prantilla, J.N.D. \& Laureto, A.S. (2013) Adaptation to Climate Change of Lowland Rice Farmers in Bukidnon, Philippines: A Micro-Level Analysis. Biennial convention of Philippine Agricultural Economics and Development on 'Inclusive and Sustainable Development: Issues and Challenges for Agriculture, Fishery and Natural Resources'. p. 18.

\section{Simelton, E., Quinn, C. H., Batisani, N., Dougill, A.} J., Jen, C., Fraser, E. D. G., Mkwambisi, D., Sallu, S. \& Stringer, L. C. (2013) Is rainfall really changing? Farmers' percep- tions, meteorological data, and policy implications. Climate and Development $37-41$. doi:10.1080/17565529.2012.751893

SPORE (2008) Climate Change, Spore, Special Issue-August.

Thomas, D.S.G., Twyman, C., Osbahr, H. \& Hewitson, B. (2007) Adaptation to Climate Change and Variability: Farmer Responses to Intra-Seasonal Precipitation Trends in South Africa, Climate Change 83, $22-31$.

Tobler, C., Visschers, V.S.M. \& Siegrist, M. (2012) Addressing Climate Change: Determinants of Consumers' Willingness to Act and Support Policy Measures, Journal of Environmental Psychology 32, 197 - 207. 